Journal of Educational Research in Developing Areas (JEREDA)

Vol. 1. Issue 2, Pp. 153-166, 2020

http://www.jeredajournal.com

E-mail: info@jeredajournal.com

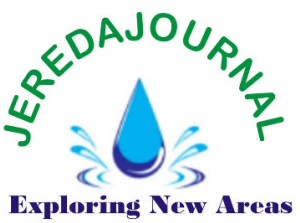

Research Article DOI: https://doi.org/10.47434/JEREDA/

eISSN: $2735-9107$

\title{
CAREER PLATEAUING AND ITS RELATIONSHIP WITH SECONDARY SCHOOL TEACHERS' PURSUIT OF POST-GRADUATE STUDIES IN NYANDARUA AND MURANG'A COUNTIES, KENYA
}

\author{
${ }^{1}$ Mary Gaturu, ${ }^{2}$ Felicita Wanjiru Njuguna
}

\author{
${ }^{1}$ National Office, Assurance and Standards, Ministry of Education, Kenya \\ ${ }^{2}$ Education Management Policy and Curriculum Studies, Kenyatta University, Kenya. \\ Email: ${ }^{1}$ marygaturu@yahoo.com
}

Corresponding Author: ${ }^{2}$ wanjisjnu@gmail.com

(10) https://orcid.org/0000-0002-7062-7816

Received: $26^{\text {th }}$ August, 2020; Revised: $26^{\text {th }}$ September, 2020; Accepted: $15^{\text {th }}$ October, 2020

\begin{abstract}
Introduction: Kenyan teachers showed signs of plateauing in employment. This research examined whether the career plateauing was related to of teachers seeking postgraduate studies.

Purpose: The study aimed at determining the types of career plateuing faced by public school teachers in secondary schools and to determine the relationship between career plateauing and the decisions of teachers to undertake different postgraduate courses.

Methodology: The research employed correlational study design. The target population was 5,022 teachers, and 304 from Nyandarua and 348 from Murang'a Counties. A representative sample was determined using the formula by Krejcie \& Morgan, which is used to calculate a sample size of 652 . A questionnaire was used for data collection, and its relevance was reinforced by the experience of supervisors and other lecturers at the university. Test-Retest methodology was used to determine the reliability of the questionnaire and found a correlation coefficient of 0.86 . The data were analyzed using descriptive and inferential statistics. Pearson Product Moment correlation coefficient, variance analysis and chi-square were used at 0.05 level of confidence.

Results: Most teachers in the study did not experience career plateauing. There was a significant relationship between structural plateauing and nature of postgraduate course attended although there was no significant relationship across the entirety of the courses attended and overall career plateauing.

Recommendations: The Teachers Service Commission should create a consistent roadmap for teachers' career development to address career plateauing and, in partnership with the Ministry of Education, should improve teachers' skills upgrades through capacity-building initiatives that should form the basis for promotion.
\end{abstract}

Keywords: Plateauing career, Postgraduate course, Teachers, Relationship, Teachers' pursuit.

\section{Cite paper as:}

Crossref Gaturu, M., \& Njuguna, F. W. (2020). Career plateauing and its Cited-by relationship with secondary school teachers' pursuit of post-graduate studies in Nyandarua and Murang'a counties, Kenya. Journal of Educational Research in Developing Areas, 1 (2), 153-166. https://doi.org/10.47434/JEREDA.1.2.2020.153.

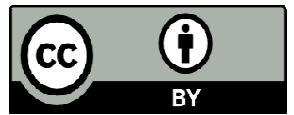

Copyright (c) 2020 The author(s) of this article retain(s) the copyright.

Volume 1, Number 2 


\section{PUBLIC INTEREST STATEMENT}

The authors noted that many teachers were either leaving the profession or going back to study in higher institutions of learning with a view to preparing themselves for better places in the job market. This study is significant in that the authors wished to establish whether there was a relationship between plateauing and taking up more courses. This study results were expected to inform the Teachers Service Commission (TSC) of the situation as one of the resaons why they were loosing many teachers and therefore the perenial shortage of teachers.

\section{INTRODUCTION}

Career plateauing is a term that refers to a sense of discontent encountered by employees within an organization when career development prospects are no longer available (Choudhary, Ramzan \& Riaz, 2013). It was described as one of the teaching profession's traits (Atteberry, Loeb \& Wyckoff, 2013). This research proposed structural plateau and job content as the two types of career plateauing found in the teaching profession. In the teaching profession, prospects for advancement are minimal, and the 'routine' nature of the teaching job means teachers can reach a point where they feel their job duties are no longer challenging. Once teachers hit a career plateau, much like workers in other industries, they search for ways to fix the career plateau. What is unknown is whether pursuing further studies is one approach teachers use to fix career plateauing.

Although numerous studies on the factors associated with the teacher career plateau have been conducted in developed and developing countries, little research has considered whether there is a link between career plateauing and teacher decision to undertake postgraduate courses. In Kenya, Katula and Orodho (2014) found that the key explanatory variables affecting teaching in Kenya were job dissatisfaction among teachers as a result of low motivation and remuneration, restricted promotional avenues and professional growth as a result of unsupportive schools and government policies. According to Mungai (2015), most teachers in Kenya believe the teaching profession is no longer enjoyable; and does not commands the high status it enjoyed thirty years ago, with the teaching today being considered by most school leavers and university graduates as 'jobs of last resort.' Waga and Simatwa (2014) have also indicated that there is restricted promotional opportunity within the teaching profession. These three causes the feeling that teaching profession is no longer fun, the lack of demanding job tasks and the lack of prospects for advancement - were related to the career plateauing.

Researchers have shown that teaching work in Kenya is characterized by a perception that the teaching job is no longer fun (Mungai, 2015), and lack of promotional opportunities (Waga \& Simatwa, 2014). These variables were linked to career plateauing. However, no research to ascertain this connection has been carried out in Kenya so far. When teachers apply for further study, some seek non-educational courses (such as Education Management, Guidance and Counseling, or Master's Degrees in their teaching subjects, while others seek noneducational courses (such as Business Administration, Gender and Development Studies). What is not clear are the factors which influence the decisions of teachers on which courses to follow. Do they follow courses that increase their chances of advancement in the profession and thus overcome the systemic plateauing, or courses that increase the chances of being employed in other sectors with more demanding job tasks, thus overcoming the plateauing of work content? Therefore the study investigated whether there was a link between career plateauing and the decision to pursue higher education among Kenyan secondary school teachers in Nyandarua and Murang'a counties, Kenya.

The research was based upon the Ference, Stoner and Warren (1977) Managerial Careers Model. Which provides an explanation for the issue of 
plateaued workers. The model outlines key career stages of the plateauing process. There are four groups of workers as outlined in Table 1 . Solid, Stars, Deadwood and Comers - based on their present ability and the probability of future promotion (Ference, Stoner \& Warren, 1977). The classification of these is given in table 1 .

Table 1: A Model of Managerial Careers

\begin{tabular}{lll}
\hline Current Performance & \multicolumn{2}{l}{ Likelihood of future promotions } \\
\cline { 2 - 3 } High & Low & High \\
\cline { 2 - 3 } & $\begin{array}{l}\text { Solid Citizens } \\
\text { (Organizationally or } \\
\text { Personally Plateaued) }\end{array}$ & $\begin{array}{l}\text { Stars } \\
\text { (Not Plateaued) }\end{array}$ \\
Dew & $\begin{array}{l}\text { Deadwood } \\
\text { (Ineffectively Plateaued) }\end{array}$ & $\begin{array}{l}\text { Corners } \\
\text { (Non-Plateaued) }\end{array}$ \\
\hline
\end{tabular}

Source: Ference, Stoner and Warren (1977).

Solid citizens are people whose performance is satisfactory but who, for organizational or personal reasons, the company believes have little hope of being promoted. These workers have plateaued and are likely to develop their skills in order to provide successful service and therefore gain promotion. In relation to the study they are teachers who are likely to undertake teaching career-related courses in order to attract promotion within the profession. Stars have above current job results, and on a growth stage and still have room for future success. These workers are dedicated, hard-working, and competitive on a fast career track. Stars may be those teachers who have not experienced either structral plateauing or job content plateau. They may undertake postgraduate studies to improve their professional skills and performance. Deadwoods are individuals whose performance is below expectations and who, in the company that fears career stagnation, may have minimal possibilities for advancement. They felt their jobs gave them fewer opportunities to participate in ventures that were accessible to top management, and their services were less marketable to other organisations. Both structurally and in terms of job content they are plateaued.

Comers are individuals that the company has defined as having a high potential for advancement but their current output is below their potential. Research has shown that workers who are unsure about what they want to do have less success than those employees who are committed to their jobs. Comers are still in the auto exploration process. This may be the young and inexperienced newly hired teachers and are not plateaued yet. The Models was used because it provides an understanding for the the plateued employee problem and provides it further categorises employees likelihood of future promotion hence it relates with the study on career plateuing.

The literature reviewed hereby focuses on the forms of career plateau faced by teachers, the relationship between career plateauing and teacher decision to pursue postgraduate studies, history features associated with career plateauing. Two forms of career plateau are observed from Bardwick (1986): job content plateau, and hierarchical (or structural) plateau. Job content plateau occurs as a result of the work itself being largely not challenging. Employees feel unchallenged by the day-to-day jobs and duties they undertake. On the other hand, as a result of workers having little to no chance to further develop the company, the hierarchical (to structural) plateau exists (Bardwick, 1986). Another categorization of career plateauing is offered by Burke and Mikkelsen (2006), who claim that there is a third type, besides structural and material plateaus, 
which they refer to as life plateauing. They describe life plateauing as the feeling of an employee being trapped or stuck outside of the job in his or her positions.

Although career plateauing has been related to both positive and negative organizational outcomes, researchers including Lee (2003) and Tremblay, Roger and Toulouse (1993) have shown more negative outcomes in plateauing. Hierarchical plateauing, for example, is correlated with employee absenteeism, low levels of supervisory satisfaction, more health issues, high levels of work-related tension and burnout, and high turnover intentions (Tremblay \& Roger, 1995). In addition, hierarchical plateauing has led to low levels of work satisfaction, lack of organizational engagement and weak job performance (Chao, 1990; Milliman, 1992; Allen, Russell, Poteet, Dobbins, 1999). One of the goals of this study was to recognize the kinds of career plateauing faced by teachers in Kenya's public secondary schools.

Teachers often regard nonmonetary benefits such as encouragement from fellow teachers and school administrators as a significant aspect to be considered when making career decisions. Other considerations include, and are not limited to, demanding job duties, advancement opportunities, quality of school infrastructure, available resources, participation in decision-making processes, learner attitudes and scheduled teaching hours. These working conditions will depend on the type of school, where the school is located and the pupils, parents and students demographics.

Human capital can be improved by in-service training, educational progression by formal schooling, induction courses or any other programme intended for professional growth and development. According to Kirby and Grissmer (1993), training is referred to as general training, where one acquires skills which can be applied to other practitioners for the purpose of salary enhancement and other benefits.
On the other hand, specialized training is explicitly tailored to develop the human resources for a business, such as teacher training in a particular school for the purpose of his work. It is a training unique to a school where a teacher or some other educator is operating in (Kirby \& Grissmer, 1993). In this research, figuring out the motivating factors behind the preference of teachers to undertake postgraduate courses will be of interest. Dixon and Ward (2015) explored the factors teachers pursue a Master's Degree and the sort of workplace support that was provided during their enrolment. The research, involving 18 practitioners, found that the reasons for pursuing academic study were closely related to their understanding of what it means to be a teacher and how teaching and learning can be enhanced. Dixon and Ward (2015) indicated that the professional identity of teachers tends to represent the teaching discourse as a dynamic, professional practice. Such an approach appeared contrary to that of many colleagues and senior managers in their workplace who provided the teachers with implicit signals about the relevance and significance of study and analysis to professional practice.

Williams (2005) conducted a qualitative review of six experienced teachers in New Zealand, in order to assess the role of academic research in professional development for teachers. The study found that the main contributing factors to teacher learning included: the opening of their minds to different perspectives; the need to analyze and synthesize ideas, knowledge and concepts as part of in-class discussion and evaluation tasks; the importance of theory; and the role of reflection and collaboration with other people. Williams (2005) concluded that postgraduate studies have the ability to bring about significant change in the thought and practice of teachers and thereby make a critical contribution to their professional learning. Harvey (2005) conducted a survey of the motivating factors that affect the involvement of teachers in postgraduate 
learning. Study participants $(\mathrm{N}=178)$ included primary and secondary teachers at five Christian schools located in Queensland, Australia's south-east region. The study described the strongest motivators for teachers engaged in postgraduate research as the desire to develop knowledge and skills in specific subject areas (pedagogical content); the desire to serve their students more meaningfully and to help their students learn better (to serve and allow students); and the opportunity to explore the beliefs and values that underlie educational issues and the trends. The studies discussed above tend to indicate that all teachers who are pursuing postgraduate studies are doing so in order to become better teachers. The studies may not show whether there are teachers whose intention to undertake further studies is to obtain jobs outside the teaching profession in other sectors. This research, as one of the aims, aimed to establish if there are teachers who, as a result of experiencing career plateauing, are participating in further studies with a view to being promoted or improved in the teaching profession.

\section{STATEMENT OF THE PROBLEM}

Career plateauing is a significant problem for any organization, as it leads to low morale of workers, decreased productivity and turnover of employees. Within Kenya's education market, teachers see teaching work as no longer fun, lacking demanding job assignments, and missing prospects for promotion. Those three causes are career plateauing markers. It is noted that many teachers have enrolled in the various universities in the country for postgraduate studies. When teachers apply for further study, some follow non-educational courses (such as Educational Management, Guidance and Counseling or Master's Degrees in their teaching subjects) while others follow non-educational courses (such as Business Administration, Gender and Development Studies). However, what was not evident were the factors affecting the decisions of the teachers about the courses to follow. Do they follow courses that increase their chances of advancement in the profession and thus overcome the systemic plateauing, or courses that increase the chances of being employed in other sectors with more demanding job tasks, thus overcoming the plateauing of work content? Thus, the research investigated whether career plateauing relates to the decisions of teachers to undertake postgraduate studies.

\section{PURPOSE OF THE STUDY}

1. To assess the types and levels of career plateauing faced by teachers in public secondary schools in Murang'a and Nyandarua Counties.

2. to assess the plateauing of job content experience by teachers in public secondary schools in Murang'a and Nyandarua Counties

3. Determine the relationship of career plateauing and the teacher decisions to undertake postgraduate courses

\section{RESEARCH QUESTIONS}

1. What are the types and levels of career plateauing experienced by teachers in public secondary schools in Murang'a and Nyandarua Counties?

2. What is the plateauing of job content experience by teachers in public secondary schools in Murang'a and Nyandarua Counties?

3. What is the relationship between career plateauing and teachers' decisions to pursue various PostGraduate courses in the counties?

\section{METHODOLOGY \\ Research Design}

The study used correlational research design, a quantitative analysis approach in which a researcher has two or more quantitative variables from the same group of respondents to decide whether an association (or covariation) exists between the two or more variables. Correlational studies are objective, multi-subject designs in which participants were not randomly allocated to treatment conditions (Thompson, 
Diamond, McWilliam, Snyder \& Snyder, 2005). The reasoning behind using correlational design for this analysis was that the researchers collected information as is on the ground without manupilation. The research was conducted in Nyandarua and Murang'a Counties at public secondary schools in Kenya.

\section{Population and Sample}

The study targeted all the 5,022 teachers teaching at the Nyandarua and Murang'a Counties public secondary schools. There are 3,581 public secondary school teachers in Murang'a County and 1,441 teachers in Nyandarua County, according to 2016 data from the County Director of Education Offices (Murang'a and Nyandarua). A representative sample was calculated from a population of 5,022 teachers using the formula used by Krejcie \& Morgan (cited in Cohen, Manion \& and Morrison, 2007), which is used to measure a sample size (s), from a given finite population (P) such that the sample would be within plus or minus 0.05 of the population proportion with a 95 percent confidence level.

In the selection of the teachers, stratified random sampling with a proportionate allocation was used. The number of sampled units in each stratum is proportional to the size of the stratum (in this case, the counties of Murang'a and Nyandarua) such that each unit in the sample reflects the same number of units in the population (Lohr, 2010). Murang'a County has 265 public secondary schools while 135 are in Nyandarua County. These schools were used as sampling units, where stratified random sampling was used to select 40 Murang'a County schools and 40 Nyandarua County schools. Stratified random sampling was used to select the schools in the categories of National, County and District schools in each county as shown in Table 2 below:

Table 2: Sampling matrix for schools

\begin{tabular}{lllll}
\hline \multirow{2}{*}{ Category of school } & \multicolumn{2}{l}{ Murang'a County } & \multicolumn{2}{l}{ NyandaruaCounty } \\
\cline { 2 - 5 } & Population & Sample size & Population & Sample size \\
\hline National schools & 2 & 2 & 2 & 2 \\
County schools & 25 & 10 & 17 & 10 \\
Sub-County schools & 238 & 28 & 116 & 28 \\
\hline Total & $\mathbf{2 6 5}$ & $\mathbf{4 0}$ & $\mathbf{1 3 5}$ & $\mathbf{4 0}$
\end{tabular}

Source: KNEC (2014)

The targeted sample size from the 80 schools was 304 teachers from Nyandarua County, and 348 teachers from Murang'a County. In Nyandarua County the sample size was 152 male and 152 female teachers, while 174 male and 174 female teachers were selected from Murang'a County. Getting equal numbers of male and female teachers per county was in the interests of the researchers.

\section{Instrument for Data Collection}

The researchers obtained a letter of introduction and research permit from the relevant offices and institutions. All sampled schools was visited and data collected from the questionnaires aministered to the targeted teachers. The respondents were assured of confidentiality after which they were given ample time to complete the questionnaires, after which the researchers collected the filled-in questionnaires. The choice of questionnaires as data collection tools was based on the fact that questionnaires are capable of producing detailed responses that are easy to interpret, allow group comparison, and are timeefficient (Amin, 2005).

There were four parts of the questionnaire. Section one gathered participants demographic features such as; gender, age, academic qualifications. Section two collected career plateauing 
data, according to which a scale was designed to measure the degree to which teachers reached plateaus of structural and job content. Section 4 collected data on whether teachers have pursued, or intend to pursue postgraduate studies. Prior to the study, a pilot study was conducted among 15 teachers in the county of Nyandarua and 15 teachers in the county of Murang'a. The purpose of the pilot study was to evaluate and enhance questionnaire reliability and validity. The test-retest reliability testing methodology was used to determine the research instruments' reliability. Twice, within a two-week period, the questionnaires were administered to the pilot study respondents, during which the researchers compared the two sets for each respondent in order to find out whether the answers were appropriate. The Pearson Product-Moment Correlation formula was used to determine a correlation coefficient for the two experiments. For this analysis a reasonable reliability coefficient of at least 0.7 was reasonable. The validity of an instrument had been enhanced by experts, and the researchers had requested assistance from the supervisors and other university lecturers who are research experts to ensure instrument validity.

\section{Procedure for Data Analysis}

Data collected was cleaned to ensure completeness and ensure no errors and omissions. The cleaned data was then coded and analysis was done using version 21 of the Statistical package for Social Sciences ( SPSS). This research produced quantitative data, so quantitative data analysis techniques were used to analyze the obtained data. The data were analyzed using descriptive and inferential statistics. The use of frequencies, ratios, mean and standard deviations included descriptive statistics. A Four-point Likert scale comprising 9 items was used to determine to what extent teachers experienced sentiments related to structural career plateauing. The scale ranged from 1 to 4 with 1 denoting no distance, 2 representing small scale, 3 large scale, and 4 very large scale. The Scale midpoint was a score of 2.5. Any score above 2.5 therefore denoted teachers experiencing that particular feeling to a large extent, while scores below 2.5 denoted teachers experiencing the feeling to a lesser extent.

To assess to what degree teachers encountered feelings related to job content plateauing, a four-point Likert scale containing 11 items was used. The scale ranged from 1 to 4 with 1 denoting no distance, 2 representing small scale, 3 large scale, and 4 very large scale. The Scale midpoint was a value of 2.5. Any score above 2.5 therefore denoted teachers experiencing the particular feeling to a large degree, while scores below 2.5 denoted teachers experiencing the feeling to a lesser extent. In order to determine the relationship between career plateauing and teachers' decisions to pursue various Post-Graduate courses, Analysis of Variance (ANOVA) test was carried out with the nature of courses attended as the grouping variable.

\section{Method of Data Analysis}

The data were analyzed using statistics of descriptive and inferential type. The use of frequencies, ratios, mean and standard deviations included descriptive statistics. The data analysis method involved the use of a computer spreadsheet, and for this purpose Statistical Package for Social Sciences (SPSS) has been used. To evaluate the relationship between the study's independent and dependent variables in research question 3 and 4, Pearson Product-Moment correlation analysis was estimated at the significance level of 0.05. Open-ended questions were analyzed qualitatively using content analysis based on the analysis of meanings and consequences emanating from the information provided by the respondent and contrasting answers to recorded data on career plateauing and pursuit of postgraduate studies. 
Journal of Educational Research in Developing Areas (JEREDA)

Vol. 1. Issue 2, Pp. 153-166, 2020

http://www.jeredajournal.com

E-mail: info@jeredajournal.com

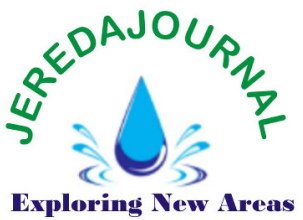

RESULTS

Reaseach Question 1: What are the types and levels of career plateauing experienced by teachers in public secondary schools in Murang'a and Nyandarua Counties?

\section{Table 3: Structural careers Plateauing}

\begin{tabular}{|c|c|c|c|c|c|c|c|c|c|c|}
\hline \multirow[t]{2}{*}{ Structural (Hierarchical) } & \multicolumn{2}{|l|}{ VGE } & \multicolumn{2}{|l|}{ GE } & \multicolumn{2}{|l|}{ SE } & \multicolumn{2}{|l|}{ NE } & \multirow[t]{2}{*}{ M } & \multirow[t]{2}{*}{ SD } \\
\hline & $f$ & $\%$ & f & $\%$ & $f$ & $\%$ & $f$ & $\%$ & & \\
\hline $\begin{array}{l}\text { My job responsibilities have } \\
\text { increased significantly }\end{array}$ & 185 & 31.0 & 307 & 51.5 & 92 & 15.4 & 12 & 2.0 & 3.12 & .730 \\
\hline $\begin{array}{l}\text { I have an expectation of } \\
\text { advancing to a higher level } \\
\text { in teaching career in the } \\
\text { near future }\end{array}$ & 256 & 43.0 & 201 & 33.7 & 95 & 15.9 & 44 & 7.4 & 3.12 & .933 \\
\hline $\begin{array}{l}\text { I have had a chance to } \\
\text { learn and grow in my } \\
\text { current job as a teacher }\end{array}$ & 133 & 22.3 & 326 & 54.7 & 125 & 21.0 & 12 & 2.0 & 2.97 & .717. \\
\hline $\begin{array}{l}\text { My duties in school give me } \\
\text { an opportunity to come into } \\
\text { contact with my supervisors } \\
\text { who can recommend for my } \\
\text { future advancement. }\end{array}$ & 199 & 33.4 & 215 & 36.1 & 119 & 20.0 & 63 & 10.6 & 2.92 & .976 \\
\hline $\begin{array}{l}\text { I expect frequent } \\
\text { promotions in the future }\end{array}$ & 178 & 29.9 & 176 & 29.5 & 161 & 27.0 & 81 & 13.6 & 2.76 & 1.03 \\
\hline $\begin{array}{l}\text { Chances for upward } \\
\text { mobility are limited in my } \\
\text { teaching career }\end{array}$ & 129 & 21.6 & 161 & 27.0 & 209 & 35.1 & 97 & 16.3 & 2.54 & 1.00 \\
\hline $\begin{array}{l}\text { I am not likely to be } \\
\text { assigned responsibilities } \\
\text { that give me a higher title } \\
\text { in my school. }\end{array}$ & 56 & 9.4 & 85 & 14.3 & 165 & 27.7 & 290 & 48.7 & 1.84 & 991 \\
\hline $\begin{array}{l}\text { I am not likely to get ahead } \\
\text { in my career. }\end{array}$ & 35 & 5.9 & 84 & 14.1 & 142 & 23.8 & 331 & 55.5 & 1.70 & .920 \\
\hline $\begin{array}{l}\text { I am at a point in my } \\
\text { career where I don't expect } \\
\text { to further promotions }\end{array}$ & 35 & 5.9 & 62 & 10.4 & 167 & 28.0 & 332 & 55.7 & 1.66 & .886 \\
\hline
\end{tabular}

As shown in Table 2, the highest ratings were: "my job responsibilities have increased significantly," "I expect to advance to a higher level in the teaching career in the near future" and "I have had the opportunity to learn and grow as a teacher in my current job." The lowest rated items, on the other hand, were: "I am at a point in my career where I don't expect further promotions," followed by "I'm not likely to get ahead in my career," and then "I am not likely to be assigned responsibilities that give me a higher title in my school." The last two columns in Table 3 show every item's means and standard deviations. The mean scores that teachers obtained on the scale measuring their feelings on the plateauing of structural career ranged from 1.66 to 3.12 . These findings indicate that most respondents reported high levels of agreement with things suggesting lack of structural plateauing, and low levels of agreement with those statements indicating the existence of structural plateauing, implying that most teachers did not experience a systemic career plateau.

Figure 1 shows the general mean and standard deviation of the structural plateauing level of the teachers which indicates graphically the levels of structural plateuing among teachers. 


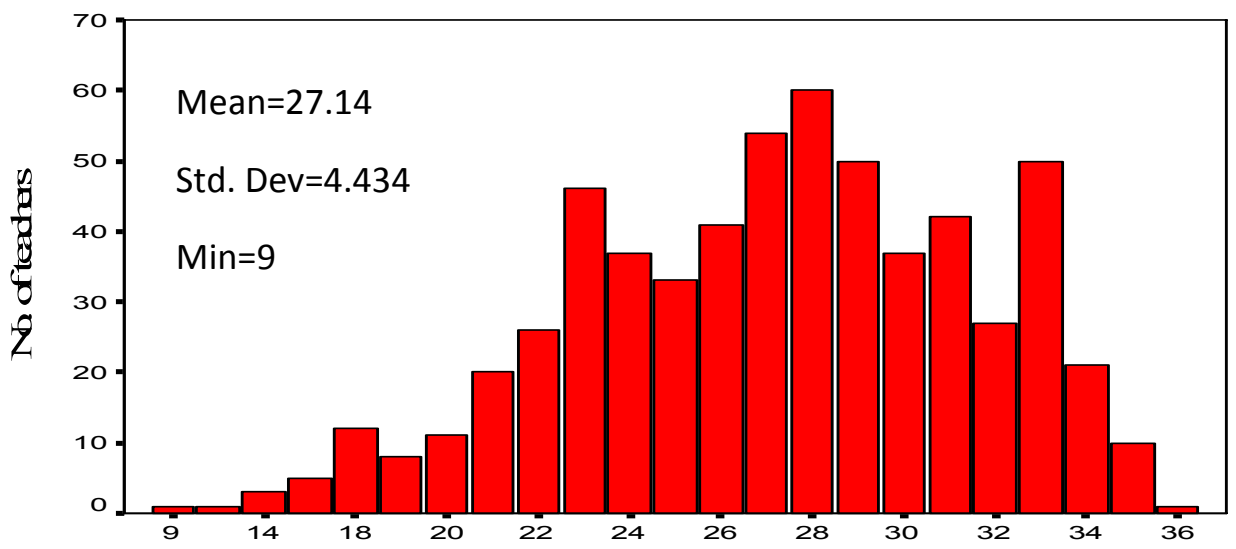

Overall scores on structural career plateauing

Figure 1: Overall Scores on Structural Career plateauing

Research Question 2: What is the plateauing of job content experience by teachers in public secondary schools in Murang'a and Nyandarua Counties?

\section{Table 4: Plateauing of job content experience by teachers in public secondary schools}

\begin{tabular}{|c|c|c|c|c|c|c|c|c|c|c|}
\hline \multirow[t]{2}{*}{ Job content } & \multicolumn{2}{|l|}{ VGE } & \multicolumn{2}{|l|}{ GE } & \multicolumn{2}{|l|}{ SE } & \multicolumn{2}{|c|}{ NE } & \multirow[t]{2}{*}{$\mathbf{M}$} & \multirow[t]{2}{*}{ SD } \\
\hline & $f$ & $\%$ & f & $\%$ & $\mathbf{f}$ & $\%$ & $f$ & $\%$ & & \\
\hline $\begin{array}{l}\text { In my job am required to } \\
\text { continually use my abilities } \\
\text { and knowledge }\end{array}$ & 350 & 58.7 & 201 & 33.7 & 36 & 6.0 & 9 & 1.5 & 3.50 & .680 \\
\hline $\begin{array}{l}\text { I persist with enthusiasm in } \\
\text { completing my work }\end{array}$ & 315 & 52.9 & 231 & 38.8 & 42 & 7.0 & 8 & 1.3 & 3.43 & .684 \\
\hline $\begin{array}{l}\text { I display dedication on the } \\
\text { job }\end{array}$ & 316 & 53.0 & 237 & 39.8 & 27 & 4.5 & 16 & 2.7 & 3.43 & .706 \\
\hline $\begin{array}{l}\text { I often voluntarily assist in } \\
\text { tasks which are not in my } \\
\text { job description }\end{array}$ & 253 & 42.4 & 251 & $42 . .1$ & 83 & 13.9 & 7 & 1.2 & 3.26 & .738 \\
\hline $\begin{array}{l}\text { I expect constant } \\
\text { challenges in my job }\end{array}$ & 206 & 34.6 & 250 & 41.6 & 108 & 18.1 & 32 & 5.4 & 3.06 & .860 \\
\hline
\end{tabular}

Key: VGE-Very Great Extent, GE-Great Extent, SE-Small Extent, NE-No Extent

Results in Table 4 show that the highest ratings were: "I need to continually use my skills and knowledge in my job," "I remain enthusiastic about finishing my job" and "I show dedication to the job." On the other hand, the lowest rated items were: "This job is too hard for me," "There's nothing exciting about this job anymore" and "My qualifications go beyond my work input, which makes me feel underused in the teaching profession." The median scores ranged from 1.40 to 3.5 for the items.
From these results it emerges that most teachers agreed with those items denoting lack of job content plateauing while disagreeing with items denoting job content plateauing presence. This is an indication that most of the study teachers didn't experience plateauing of job content.

Figure 2 shows the mean overall and standard deviation in the of the job content plateauing indicates graphically the extent of job content plateauing among teachers. 


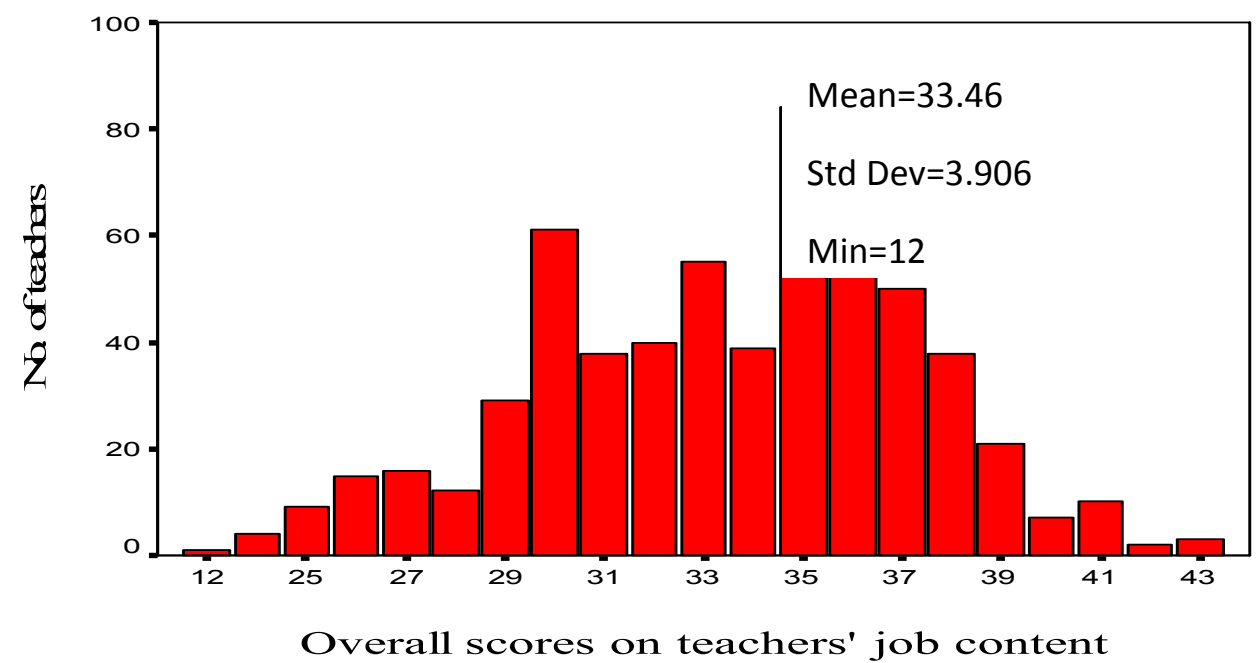

Figure 2: Overal; scores on teachers' job content

Research Question 3: What is the relationship between career plateauing and teachers' decisions to pursue various Post-Graduate courses in the counties?

\section{Table 5: ANOVA results for Career plateauing and teachers' decision to pursue postgraduate courses}

\begin{tabular}{|c|c|c|c|c|c|c|}
\hline \multirow{2}{*}{$\begin{array}{l}\text { Structural } \\
\text { plateauing }\end{array}$} & \multicolumn{2}{|c|}{ Sum of Squares } & \multirow{2}{*}{$\frac{\text { df }}{2}$} & \multicolumn{2}{|c|}{ Mean Square F } & \multirow[t]{2}{*}{ Sig. } \\
\hline & $\begin{array}{l}\text { Between } \\
\text { Groups }\end{array}$ & 139.068 & & 69.534 & & \\
\hline & $\begin{array}{l}\text { Within } \\
\text { Groups }\end{array}$ & 11560.523 & 593 & 19.495 & 3.567 & $.029 *$ \\
\hline & Total & 11699.591 & 595 & & & \\
\hline \multirow[t]{3}{*}{$\begin{array}{l}\text { Job content } \\
\text { plateauing }\end{array}$} & $\begin{array}{l}\text { Between } \\
\text { Groups }\end{array}$ & 29.408 & 2 & 14.704 & & \\
\hline & $\begin{array}{l}\text { Within } \\
\text { Groups }\end{array}$ & 9046.543 & 593 & 15.256 & .964 & .382 \\
\hline & Total & 9075.951 & 595 & & & \\
\hline \multirow[t]{3}{*}{$\begin{array}{l}\text { Overall career } \\
\text { plateauing }\end{array}$} & $\begin{array}{l}\text { Between } \\
\text { Groups }\end{array}$ & 40.661 & 2 & 20.331 & & \\
\hline & $\begin{array}{l}\text { Within } \\
\text { Groups }\end{array}$ & 28964.095 & 593 & 48.843 & .416 & .660 \\
\hline & Total & 29004.757 & 595 & & & \\
\hline
\end{tabular}

*Significant at the 0.05 level

Table 5 indicates that for structural plateauing, teachers who had attended teaching-related courses had lower mean scores than those who had attended non-teaching-related courses and those who had not attended any courses. The mean scores were found to be comparable for all teachers for job content plateauing and overall career plateauing, regardless of attendance of additional courses or otherwise. As shown in Table 5, there was a substantial difference (at $p>0.05$ ) across the scope of the courses attended in the structural plateauing of teachers with mean grades. Teachers who had attended teachingrelated courses had slightly lower mean scores than those who had attended nonteaching-related courses than those who had not attended any courses. This indicates that teachers who attended teaching-related courses encountered higher levels of structural plateauing than their peers who attended courses unrelated to the teaching profession and those who had not attended any courses. For job content plateauing and overall career plateauing, the study did not find 
any significant mean differences across the nature of courses attended.

\section{DISCUSSIONS}

The findings show that there was a substantial difference in the structural plateauing of teachers mean scores across the scope of the courses attended suggests that the goal of the teachers to undertake further studies was to develop their performance and skills to qualify for promotion. This is confirmed by the research from the results of MellorsBourne, Kemp and Humfrey (2013) which showed that teachers who completed graduate work or earned a Master's degree tended to teach longer than other undergraduate teachers. For job content plateauing and overall career plateauing, the analysis found no major mean differences over the design of the attended courses. The lack of a substantial difference between the job content plateaued teachers and nature of courses attended can be interpreted as suggesting that the goal of such teachers is to develop skills to prepare for other demanding responsibilities within the profession or in other fields. These are the teachers who may join the Ministry of Education, as Quality Assurance Officers or Education Officers. To such teachers any additional courses shall meet their objective.

The study found that teachers enrolled for post-graduate studies to improve their effectiveness in teaching so that they increase chances of promotion which is in agreement with Coolahan (2013) who suggests that people, who have reached a professional plateau, may seek opportunities to renew their intellectual commitments through further study. The finding is in tandem with Drudy (2014) who offers that postgraduate study is now becoming the norm, a trend which teachers in the profession for less than ten years displayed a keen awareness of. $\mathrm{He}$ observed that masters qualifications will become the norm within the teaching profession. Woods (2012) states that a career map is formed through observation of colleagues while Loberman and Tziner (2011) concur that this map is constructed from the peoples' own perceptions of the career performance of significant peers which is underpinned by values. Masters Degree is clearly valued in society and this concept along with the Masters Degree becoming the norm explains the emergent culture whereby teachers are pursuing masters in order to be at the same level as their colleagues, both in terms of qualifications and in terms of the perceived status in their working context. Kellaghan (2012) highlights this shift towards intellectual authority and points out that individuals are now realizing what research confirms that one's personal development, life chance, earnings, status and lifestyle are likely to be considerably enhanced by having a higher education qualification. Edwards, Sieminski and Zeldin (2013) concur with these observations arguing that participation in education generally contributes to social mobility, providing a ladder of opportunities for some.

Shasti and Foster (2011) point out that other areas of assignment in school include Dormitory Teachers and Class Teachers, Club Patrons and Trainers in Drama, Coordinator of Departmental Issues, Staff Welfare, Head of Department (HOD), Games Master, Scouting Patron, Curriculum Coordinator, Library Assistant and Christian Union Patron. When more assignments were given to the teachers, some were comfortable, others challenged to maintain performance, felt involved and useful, some were discouraged and others indifferent, others felt honoured, others were shaken at first but became comfortable later. In this study, this is reflected in the finding that teachers were of the view that their job responsibilities had increased significantly in the course of their teaching career.

\section{CONCLUSION}

Based on the above findings, the study concludes that majority of the teachers were not experiencing both structural and job content career plateauing. There was a significant relationship between structural plateauing and the nature of courses attended. Teachers who attended courses 
related to teaching profession were experiencing high level of structural plateau than the counterpart who attended courses unrelated to the profession. There was no significant relationship between job content plateauing and nature of courses attended. When teachers experienced structural, job content or both types of plateau, they are likely to respond by enrolling for post graduate studies as one way of addressing plateauing, hence there was a significant relationship between career plateau and the teachers decision to pursue further studies.

\section{RECOMMENDATIONS}

1. Teachers Service Commission should create a consistent roadmap for teachers career advancement.

2. The Teachers Service Commission should establish skills upgrades for teachers in collaboration with the Ministry of Education through capacity-building programmes which should be a prerequisite for those who enter the profession and which should form the basis for promotion

Conflicts of Interest: The authors declare no conflict of interest.

\section{Acknowledgments}

Ogeta Norbert is acknowledged as one of the supervisors but with minimal role. He was not involved in writing the paper.

\section{Disclaimer Statement}

The journal article has been developed from 2 objectives of Thesis in which one of the author was awarded Doctor of philosophy degree. The title of the thesis was "Career plateauing and its relationship with turnover intentions and pursuit of post-graduate studies among teachers in Nyandarua and Murang'a counties, Kenya" presented to Department of Education Management, Policy and Curriculum Studies in Kenyatta University, Kenya.

\section{Notes on Authors}

Mary Gaturu now works in a national office in Kenya with the Ministry of Education as the Director of Quality Assurance and Standards. At the time of her study, she was the Director of Education at Muranga County Level as well a Quality Assurance officer earlier. Her interests are gender, education and is highly experienced in matters of education admistration.

Felicita Wanjiru Njuguna is a senior lecturer in Educational Management and Policy at Kenyatta University. Her research interests are in gender, policy and management of education. She is the chair of Muranga County Education Board and Chair of Women Educational Researchers of Kenya, also a member of ANIE- African Network of Internationalisation of Education among others.

\section{Authorship and Level of Contributions}

Mary Gaturu undertook, conceived and wrote the introduction, statement of the problem, purpose of the study, research questions, formulation of hypotheses and the methodology adopted. She developed the instrument and administered it.

Felicita Wanjiru Njuguna did the analysis, testing of the hypothesis, generate the results and interpretation. She came up with the conclusion and the recommendations for the study.

\section{REFERENCES}

Allen, T. D., Russell, J. E. A., Poteet, M. L., \& Dobbins, G. H. (1999). Learning and development factors related to perceptions of job content and hierarchical plateauing. Journal of Organizational Behaviour, 20 (7), 11-13.

Amin, E. M. (2005). Social science research: Conception, methodology and analysis. Makerere University Printery.

Atteberry, A., Loeb, S. \& Wyckoff, J. (2013). Do first impressions matter? Improvement in early career teacher effectiveness, 
Working Paper No. 90 http://auth.calder.commonspotclou d.com/publications/upload/wp90.pd f.

Bardwick, J. M. (1986). The plateauing trap. American Management Association.

Bluedorn, A. C. (1982). A unified model of turnover from organizations. Human Relations, 35 (2), 135-153.

Burke R.J., Mikkelsen, A. (2006). Examining the career plateau among police officers. International Journal of Police Strategies and Management, 29 (4), 691-703.

Chao, G. T. (1990). Exploration of the conceptualization and measurement of career plateau: A comparative analysis. Journal of Management, 16 (1), 181-193.

Choudhary, S. A., Ramzan, M. and Riaz, A. (2013). Strategies for career plateau: Empirical investigation of organizations in Pakistan. Interdisciplinary Journal of Contemporary Research in Business, 4 (9), 712-726.

Cohen, L., Manion, L. and Morrison, K. (2007). Research methods in education (6th ed.). Routledge/Falmer.

Coolahan, J. (2013). Attracting, developing and retaining effective teachers: Country background report for Ireland. Department of Education and Science.

Drudy, C. (2014). The in-service training of teachers in the twelve Member States of the European Community. Presses Interuniversitaires Europeenes.

Dixon, H., \& Ward, G. (2015). The value of masters' study to teachers' professional practice: Contradictory discourses within the workplace. Australian Journal of Teacher Education, 40(2), 52-65.

Edwards, R., Sieminski, S. \& Zeldin, D. (eds) (2013) Adult learners, education and training: $A$ reader. Routledge.
Ference, T. P., Stoner, J. A. F., \& Warren, E. K. (1977). Managing the career plateau. Academy of Management Review, 2 (4), 602-612.

Harvey, P. (2005). Motivating factors influencing teachers' engagement in postgraduate study: The results of a study of five schools. A paper presented at the Australian Association for Research in Education Conference 2005.

Katula, J. M., \& Orodho, J. (2014). Teachers' turnover: What are the explanatory variables in public secondary schools in Mbeere subcounty; Embu county, Kenya. Journal of Humanities and Social Science, 19 (12), 11-24.

Kellaghan, T. (2012). Preparing teachers for the 21st century: Report of the working group on primary preservice teacher education. Stationery Office

Kirby, S., \& Grissmer, D. W. (1993). Teacher attrition: Theories, evidence, and suggested policy options. Santa Monica, RAND Corporation. (ERIC Document Reproduction Service No. ED 364533).

Krejcie, R. V., \& Morgan, D. W. (1970): Determining sample size for research activities. Educational and Psychological Measurement, 30, 607-610.

Lee, P. C. B. (2003). Going beyond career plateau: Using professional plateau to account for work outcomes. Journal of Management Development, 22 (6), 538-551.

Loberman, G., \& Tziner, A. (2011). The influence of the parent-offspring relationship on young people's career preferences. Journal of work and Organizational Psychology, 28, 99-105.

Lohr, S. L. (2010). Sampling: design and analysis ( $2^{\text {nd }}$ edition). Brooks/Cole.

Mellors-Bourne, R., Kemp, N., \& Humfrey, C. (2013). The wider benefits of international higher 


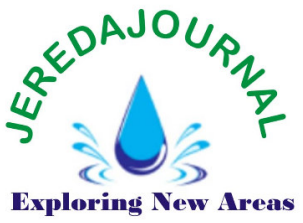

qualitative study of engagement in the field of nursing and midwifery. Journal for the Enhancement of Learning and Teaching, 4(1), 12-21.
Milliman, J. F. (1992). Causes, consequences, and moderating factors or career plateauing. University of Southern California.

Mungai, C. (2017): Africa's teachers skip school due to poor pay? Yes or No! Special Report.

Thompson, B., Diamond, K. E., McWilliam, R., Snyder, P., \& Snyder, S. W. (2005). Evaluating the quality of evidence from correlational research for evidencebased

practice.http://www.cec.sped.org/C ontent/NavigationMenu/Professional Development/ProfessionalStandards LCopy\%20of\%20Final\%20Manuscrip tCorrelational\%20Research204-604.pdf

Tremblay, M., \& Roger, A. (1993). Individual, familial and organizational determinants of career plateau: An empirical study of the determinants of objective and subjective career plateau in a population of Canadian managers. Group \& Organization Management, 18 (4), 411-425.

Shasti, R., \& Benjamin, P. F. (2011). Mentoring, career plateau tendencies, turnover intentions and implications for narrowing pay and position gaps due to gender structural equations modeling. Journal of Applied Business Research, 27 (6), 71-84.

Waga, R. A., \& Simatwa, M. W. (2014). Hygiene and motivational factors that influence job satisfaction and dissatisfaction among teachers of public primary schools in Kisumu East and West sub-Counties, Kenya: An analytical study. Educational Research, 5 (8), 296-314.

Williams, R. (2005). The role of academic study in teachers' professional development. Journal of In-service Education, 31 (3), 455-470.

Wood, P. (2012). Continuing professional development in higher education: A 